\title{
Effect of Azotobacter, Pseudomonas and Bio-Regulators on Yield Attributes and Yield of Garlic (Allium sativum L.)
}

\author{
Ganpat Lal Yadav ${ }^{*}$, S. P. Singh ${ }^{1}$, R. K. Yadav ${ }^{2}$ and Bhagchand Yadav ${ }^{1}$ \\ ${ }^{1}$ Department of Horticulture, S.K.N. College of Agriculture, Jobner \\ (S.K.N. Agriculture University, Jobner, Jaipur) 303328 Rajasthan, India \\ ${ }^{2}$ Agricultural Research Station, Ummedganj, AU Kota, India \\ *Corresponding author
}

\section{Keywords}

Azotobacter, PGPR

(Pseudomonas), thiourea, salicylic acid and mepiquat chloride

\section{Article Info}

Accepted:

05 April 2020

Available Online:

10 May 2020

\section{A B S T R A C T}

A field experiment was conducted at Horticulture Farm, S.K.N. College of Agriculture, Jobner (Jaipur) during Rabi season 2016-17 and 2017-2018. The experiment consisting four bio-fertilizers (control, Azotobacter, PGPR (Pseudomonas) and Azotobacter + PGPR (Pseudomonas) and five bio-regulators (control, Thiourea @ 500 ppm, Thiourea @ 1000 ppm, salicylic acid@100 ppm and mepiquat chloride@100 ppm). The total 20 treatment combinations were tested in split-plot design with three replications. Application of biofertilizers: Azotobacter + also significantly increased the neck thickness, polar diameter, fresh weight of bulb, dry weight of bulb, number of cloves per bulb, bulb yield (kg/plot), bulb yield ( $\mathrm{q} / \mathrm{ha}$ ) and net returns as compared to control. Foliar application of thiourea @ $1000 \mathrm{ppm}$ to the garlic crop significantly increased the being statistically at par with application of thiourea@500 ppm and salicylic acid@100 ppm. Further, it can be concluded that combined application of Azotobacter + PGPR (Pseudomonas) along with thiourea@1000 ppm proved to be most superior treatment combination as it fetched comparable bulb yield (223.58 q/ha) followed by Azotobacter + PGPR (Pseudomonas) along with thiourea @ 500 ppm and Azotobacter + PGPR (Pseudomonas) along with salicylic acid @ 100 ppm.

\section{Introduction}

Garlic is the second important bulb crop after onion. Botanically it is known as Allium sativum, which belongs to the family Amaryllidaceae. It is a multiple or compound bulb consists of smaller bulblets called 'cloves' and is surrounded by a thin white or pinkish papery sheath. The economic yield is obtained from these cloves. As bio-fertilizers are the recent sources for fixation of atmospheric nitrogen in to the soil and making it readily available for the growth of plants. Among the bio-fertilizers, Azotobacter though having limited use in vegetables, yet has established its bio-activity in cereals, oilseeds and other crops for mobilizing the useful macro nutrients from unusable to 
usable state and increase the crop production by enhancing soil fertility. In addition, the bio-fertilizers not only supplement the nutrition but also improve the efficiency of applied nutrients (Somani et al., 1990).

Further, Pseudomonas fluorescens is common non-pathogenic saprophyte that colonizes in soil, water and on plant surfaces. It produces a soluble greenish fluorescent pigment. It suppress plant diseases by protecting the seeds and roots from fungal infections by production the number of secondary metabolites including antibiotics, siderophores and hydrogen cyanide. This microbe has the unique ability to enter the plant vascular system and reach to the various parts of the plant system and act as a systemic bio-control agent against various fungal and bacterial diseases. It is applied as Seed treatment @ 4-5 g per kg of seeds as per standard wet treatment (Yawalkar et al., 1996). Furthermore, thiourea plays a vital role in the physiology of plants both as a sulfhydryl compound and to some extent as an amino compound like urea. The stimulating action of thiourea in various physiological activities of plant is well known. It has also been reported that thiourea regulate the plant growth by maintaining higher photosynthetic rate upto the reproductive stage and increased the yield by improving carbon partitioning towards sink (Anonymous, 1999). The stimulating action of thiourea in various physiological activities of plant is well known. Thiourea is mainly known for its dormancy breaking and germination stimulating effect (Mayer, 1956; Mayer and Poljak off-Mayber, 1958). The dormancy breaking effect of thiourea was suggested to be related to its growth enhancing effect.

Similarly salicylic acid is one of the important bio-regulator which positively affects growth of plants. It is classified as phenolic growth regulator, a non- enzymatic antioxidant, a signaling or messenger molecule in plants to induce responses of plants to environmental stressors. SA plays an important role in the regulation and development of ion uptake, transport and membrane permeability (Simaei et al., 2012).

Salicylic acid (SA) or ortho-hydroxy benzoic acid is a common plant-produced phenolic compound. Which contributes in the regulation of physiological, biochemical and molecular processes and therefore, it affects the plant growth, development and productivity (Hayat et al., 2010).

\section{Materials and Methods}

The experiment was laid out in Split Plot Design and replicated three times. The treatments were randomly allotted to different plots using random number table of Fisher and Yates (1963). The seeds of cv. G 282 procured from NHRDF, Karnal (Haryana). The seeds (cloves) of garlic were first treated with Carbendazim @ $2 \mathrm{~g}$ per $\mathrm{kg}$ seed to control seed borne diseases. The seeds were sown on $3^{\text {rd }}$ November, 2016 and $8^{\text {th }}$ November, 2017 manually with a seed rate of $500 \mathrm{~kg} / \mathrm{ha}$ in row at $15 \mathrm{~cm}$ apart.

It is also known as Yamuna Safed-3. The variety has done very well in Northern parts and also in Central parts of India. It was developed by mass selection technique from a local collection obtained from Dindigul (TN) in 1990. The leaves are wider than other varieties. Bulbs are creamy white and bigger sized (5-6 cm diameter), size index 27-29 $\mathrm{cm}^{2}$, diameter of cloves 1.2-1.5 cm., 15-18 number of cloves per bulb, TSS 38-42\%, dry matter $39-43 \%$ and medium storer. Average yield is $175-200 \mathrm{q} / \mathrm{ha}$. The variety is suitable for export and was notified in the year 1999 vide notification no.1092 (E) dated 26/10/1999. 
Application of bio-fertilizers have done as per treatments. For this, $125 \mathrm{~g}$ of Jaggery was mixed in one litre of boiled water. Appropriate quantity of Azotobacter $50 \mathrm{~g}$ of culture was poured in Jaggery solution separately and stirred well. The seeds were allowed to air dry in shade. The cloves were sown on the same day after inoculation. The process of inoculation was preceded by clove treatment with fungicide then clove inoculation with Azotobacter and Pseudomonas fluorescens before the sowing by putting seeds in 20 per cent sucrose solution and then inoculated with respective culture @ $10 \mathrm{~g} / \mathrm{kg}$ of seeds by putting the uniform coating of chalk powder on seeds and was allowed to air dry in shade. The seeds were sown on the same day after inoculation. The seeds of control plot were treated with sucrose solution only.

The recommended dose of NK for garlic was applied @ 120:100 kg/ ha, respectively. Full dose of potassium and half dose of nitrogen were applied as basal dose just before sowing and rest half dose of nitrogen was applied as top dressing in two split doses. To protect the crop from blight and purple blotch the crop was sprayed twice with Diathane M-45 at the rate of 0.25 per cent while for the garlic thrips, the crop was also sprayed twice with Malathion@0.1\%.

\section{Results and Discussion}

It is apparent from the data presented in Table-1 that different levels of bio-fertilizers significantly influenced the neck thickness of garlic during both the years as well as in pooled analysis. Analysis of pooled data indicated that application of Azotobacter + PGPR represented maximum $(0.73 \mathrm{~cm})$ in neck thickness, which was significantly superior over all the bio-fertilizers applied. This treatment $\left(\mathrm{B}_{3}\right)$ registered an increase of 19.67 per cent higher neck thickness over control. Spray of thiourea @1000 ppm recorded maximum neck thickness $(0.72 \mathrm{~cm})$ whereas, minimum was recorded under control. The magnitude in increase of neck thickness with the application of thiourea @ 1000 ppm / ha was 20.0 per cent over control. The maximum value was recorded in the treatment Azotobacter + PGPR which was significantly superior over rest of the treatments. "These findings are in close conformity with the findings of Kore et al., (2006).

An increase in yield attributing characters with foliar application of thiourea might have induced large number of reproductive sinks leading to greater activity of carboxylating enzymes resulting in higher photosynthetic rates with greater translocation and accumulation of metabolites in sink and ultimately higher yield (Nehra et al., 2006). Analysis of pooled data indicated that combined application of Azotobacter + PGPR represented maximum $(6.73 \mathrm{~cm})$ and significantly superior polar diameter of bulb among bio-fertilizers applied. This treatment had better effect and represented the maximum increase of 19.96 per cent in polar diameter of garlic over control. Further bioregulators also significantly increased the polar diameter of bulb of garlic during both the years as well as in pooled analysis.

Spray of thiourea @ 1000 ppm recorded maximum polar diameter of bulb $(6.58 \mathrm{~cm})$. The magnitude in increase of polar diameter of bulb with the application of thiourea @ 1000 ppm / ha was registered 21.17 per cent over control. Pachouri et al., (2005) and Anonymous (2007) reported that application of Azotobacter + PGPR resulted in significantly highest bulb yield over rest of the treatments. Foliar spray of thiourea was also recorded by Balai and Keshwa (2011), Shanu et al., (2013) in coriander and Gupta and Yadav (2009) in fenugreek. 
Different levels of bio-fertilizers significantly influenced the fresh weight of bulb in garlic during experimentation. Combined application of Azotobacter + PGPR represented significantly maximum (49.77 g) fresh weight of bulb among all the treatments. This treatment also represented the maximum increase of 22.64 per cent fresh weight of bulb over control.

Examination of pooled data revealed that spray of thiourea @ 1000 ppm recorded maximum fresh weight of bulb (49.53 g) whereas minimum (39.05 g) was recorded under control. The increase in fresh weight of bulb with the application of thiourea @ 1000 $\mathrm{ppm} /$ ha was registered 26.83 per cent higher over control. The obtained results are agreement with the result of Jaafari and Hadavi (2012a) and Jaafari and Hadavi (2012b).

Combined application of Azotobacter + PGPR represented maximum and significantly higher dry weight of bulb (29.11g) among all the treatment and represented 55.25 per cent increase in dry weight of bulb over control. Foliar spray of thiourea @ 1000 ppm recorded maximum dry weight of bulb (27.72 g) and found significantly superior over rest of the treatments except $\mathrm{P}_{1}$ and $\mathrm{P}_{3}$ which were statistically at par to it.

The magnitude in increase of dry weight of bulb with the application of thiourea @ 1000 ppm / ha was 50.98 per cent over control. Similar response with foliar spray of thiourea was also recorded by Balai and Keshwa (2010) and Bochalia et al., (2011) in fenugreek. Interactive effect of different levels of bio-fertilizers and bio-regulators had significantly effected on fresh weight of bulb during both the years as well as in pooled data. Data mentioned in table 2 indicated that combined application of Azotobacter + PGPR and thiourea @ 1000 ppm $\left(\mathrm{B}_{3} \mathrm{P}_{2}\right)$ showed significantly higher fresh weight of bulb over rest of treatments except $\left(\mathrm{B}_{3} \mathrm{P}_{1}\right),\left(\mathrm{B}_{3} \mathrm{P}_{3}\right)$, $\left(\mathrm{B}_{3} \mathrm{P}_{2}\right),\left(\mathrm{B}_{1} \mathrm{P}_{2}\right)$ and $\left(\mathrm{B}_{3} \mathrm{P}_{3}\right)$ which were found statistically at par to it.

It is apparent from the data presented in table 3 that different levels of bio-fertilizers significantly influenced the number of cloves per bulb of garlic during both the years as well as in pooled data. Analysis of pooled data indicated that combined application of Azotobacter + PGPR represented significantly maximum number of cloves per bulb (18.89) among all bio-fertilizers. This treatment also represented the maximum increase of 19.70 per cent in number of cloves/bulb over control. Analysis of pooled data indicated that combined application of Azotobacter + PGPR produced significantly maximum bulb yield of $3.73 \mathrm{~kg} / \mathrm{plot}$ among all the treatment and registered 22.69 per cent higher bulb yield per plot of garlic over control.

Spray of thiourea @ 1000 ppm recorded maximum bulb yield $(3.71 \mathrm{~kg} / \mathrm{plot})$ and found significantly superior over rest of the treatments except $\mathrm{P}_{1}$ and $\mathrm{P}_{3}$ which, were statistically at par to it. The magnitude in increase of bulb yields per plot with the application of thiourea @ 1000 ppm / ha was 26.62 per cent over control.

Combined application of Azotobacter + PGPR represented significantly maximum bulb yield ( $207.37 \mathrm{q} / \mathrm{ha}$ ) over all the treatments and this treatment represented the maximum increase of 22.63 per cent in bulb yield $\mathrm{q} / \mathrm{ha}$ over control. Spray of thiourea @1000 ppm recorded significantly maximum bulb yield (206.36 q/ha) over rest of the treatment except $\mathrm{P}_{1}$ and $\mathrm{P}_{3}$ which found statistically at par to each other, where as it was noted minimum $(162.71 \mathrm{q} / \mathrm{ha})$ under control. The magnitude in increase of bulb yields with the application of thiourea@1000 ppm/ha was 26.82 per cent over control. 
Table.1 Effect of bio-fertilizers and bio-regulators on neck thickness, polar diameter, fresh and dry weight of garlic bulbs

\begin{tabular}{|c|c|c|c|c|c|c|c|c|c|c|c|c|}
\hline \multirow[t]{2}{*}{ Treatments } & \multicolumn{3}{|c|}{ Neck thickness (cm) } & \multicolumn{3}{|c|}{ Polar diameter $(\mathrm{cm})$} & \multicolumn{3}{|c|}{ Fresh weight (g) } & \multicolumn{3}{|c|}{ Dry weight (g) } \\
\hline & 2016-17 & 2017-18 & Pooled & 2016-17 & 2017-18 & Pooled & 2016-17 & 2017-18 & Pooled & 2016-17 & 2017-18 & Pooled \\
\hline \multicolumn{13}{|l|}{ Bio-fertilizers } \\
\hline $\mathbf{B}_{0}$ (Control No inoculation) & 0.60 & 0.62 & 0.61 & 5.46 & 5.75 & 5.61 & 39.36 & 41.80 & 40.58 & 18.15 & 19.35 & 18.75 \\
\hline $\mathbf{B}_{1}($ Azotobacter $)$ & 0.66 & 0.67 & 0.67 & 5.99 & 6.19 & 6.09 & 44.93 & 45.64 & 45.28 & 24.33 & 25.65 & 24.99 \\
\hline $\mathrm{B}_{2}$ (PGPR) & 0.68 & 0.69 & 0.69 & 6.13 & 6.26 & 6.20 & 46.33 & 47.32 & 46.82 & 25.15 & 26.35 & 25.75 \\
\hline $\mathbf{B}_{3}($ Azotobacter + PGPR $)$ & 0.73 & 0.73 & 0.73 & 6.71 & 6.75 & 6.73 & 49.25 & 50.29 & 49.77 & 28.80 & 29.42 & 29.11 \\
\hline SEm \pm & 0.02 & 0.01 & 0.01 & 0.14 & 0.11 & 0.11 & 0.91 & 0.85 & 0.68 & 0.63 & 0.65 & 0.49 \\
\hline $\mathrm{CD}(\mathrm{P}=0.05)$ & 0.05 & 0.03 & 0.03 & 0.45 & 0.32 & 0.32 & 2.88 & 2.44 & 2.11 & 1.97 & 1.88 & 1.52 \\
\hline \multicolumn{13}{|l|}{ Bio-regulators } \\
\hline $\mathbf{P}_{0}($ Control water spray) & 0.58 & 0.61 & 0.60 & 5.35 & 5.51 & 5.43 & 38.36 & 39.75 & 39.05 & 16.91 & 19.80 & 18.36 \\
\hline$P_{1}$ (Thiourea @ 500 ppm) & 0.70 & 0.72 & 0.71 & 6.36 & 6.65 & 6.51 & 47.59 & 48.60 & 48.09 & 26.38 & 27.16 & 26.77 \\
\hline$P_{2}$ (Thiourea @ 1000 ppm) & 0.71 & 0.73 & 0.72 & 6.44 & 6.72 & 6.58 & 48.90 & 50.15 & 49.53 & 27.29 & 28.14 & 27.72 \\
\hline$P_{3}$ (Salicylic acid @ 100 ppm) & 0.69 & 0.71 & 0.70 & 6.29 & 6.51 & 6.40 & 46.86 & 48.60 & 47.73 & 26.20 & 26.81 & 26.50 \\
\hline $\begin{array}{l}\mathbf{P}_{4} \text { (Mepiquat chloride @ } 100 \\
\text { ppm) }\end{array}$ & 0.65 & 0.62 & 0.64 & 5.92 & 5.79 & 5.85 & 43.12 & 44.22 & 43.67 & 23.75 & 24.04 & 23.90 \\
\hline SEm \pm & 0.01 & 0.02 & 0.01 & 0.10 & 0.16 & 0.09 & 0.72 & 1.02 & 0.65 & 0.52 & 0.77 & 0.48 \\
\hline $\mathrm{CD}(\mathrm{P}=\mathbf{0 . 0 5})$ & 0.03 & 0.05 & 0.03 & 0.29 & 0.49 & 0.26 & 2.06 & 3.21 & 1.83 & 1.49 & 2.41 & 1.36 \\
\hline
\end{tabular}


Table.2 Interactive effect of bio-fertilizers and bio-regulators on fresh weight (g) of bulb

\begin{tabular}{|c|c|c|c|c|}
\hline Treatments & $\mathbf{B}_{0}$ & $\mathbf{B}_{1}$ & $\mathbf{B}_{2}$ & $\mathbf{B}_{3}$ \\
\hline \multicolumn{5}{|c|}{ 2016-17 } \\
\hline $\mathbf{P}_{0}$ & 37.55 & 38.00 & 38.55 & 39.33 \\
\hline $\mathbf{P}_{1}$ & 40.10 & 48.46 & 49.05 & 52.75 \\
\hline $\mathbf{P}_{2}$ & 41.55 & 49.83 & 51.13 & 53.10 \\
\hline $\mathbf{P}_{3}$ & 39.05 & 48.35 & 48.49 & 51.55 \\
\hline \multirow[t]{2}{*}{$\mathbf{P}_{4}$} & 38.55 & 40.00 & 44.41 & 49.50 \\
\hline & & & $\mathrm{SEm} \pm$ & $\mathrm{CD}(\mathrm{P}=\mathbf{0 . 0 5})$ \\
\hline \multicolumn{3}{|c|}{ For $B$ at same level of $P$} & 1.44 & 4.14 \\
\hline \multicolumn{3}{|c|}{ For $p$ at same or diff. level of $B$} & 2.49 & 7.18 \\
\hline & \multicolumn{4}{|c|}{ 2017-18 } \\
\hline $\mathbf{P}_{0}$ & 40.35 & 38.75 & 39.52 & 40.36 \\
\hline $\mathbf{P}_{1}$ & 41.10 & 49.42 & 50.07 & 53.79 \\
\hline $\mathbf{P}_{2}$ & 43.55 & 50.68 & 52.16 & 54.22 \\
\hline $\mathbf{P}_{3}$ & 43.02 & 49.33 & 49.45 & 52.59 \\
\hline \multirow[t]{2}{*}{$\mathbf{P}_{4}$} & 40.99 & 40.02 & 45.38 & 50.49 \\
\hline & & & $\mathrm{SEm} \pm$ & $\mathrm{CD}(\mathrm{P}=\mathbf{0 . 0 5})$ \\
\hline \multicolumn{3}{|c|}{ For $B$ at same level of $P$} & 1.70 & 4.90 \\
\hline \multicolumn{3}{|c|}{ For $p$ at same or diff. level of $B$} & 2.88 & 8.31 \\
\hline & \multicolumn{4}{|c|}{ Pooled } \\
\hline $\mathbf{P}_{\mathbf{0}}$ & 38.95 & 38.38 & 39.04 & 39.85 \\
\hline $\mathbf{P}_{1}$ & 40.60 & 48.94 & 49.56 & 53.27 \\
\hline $\mathbf{P}_{2}$ & 42.55 & 50.26 & 51.65 & 53.66 \\
\hline $\mathbf{P}_{3}$ & 41.04 & 48.84 & 48.97 & 52.07 \\
\hline \multirow[t]{2}{*}{$\mathbf{P}_{4}$} & 39.77 & 40.01 & 44.90 & 50.00 \\
\hline & & & SEm \pm & $\mathrm{CD}(\mathrm{P}=\mathbf{0 . 0 5})$ \\
\hline \multicolumn{3}{|c|}{ For $B$ at same level of $P$} & 1.30 & 3.66 \\
\hline \multicolumn{3}{|c|}{ For $p$ at same or diff. level of B } & 2.10 & 5.94 \\
\hline
\end{tabular}


Table.3 Effect of bio-fertilizers and bio-regulators on number of cloves per bulb and bulb yield

\begin{tabular}{|c|c|c|c|c|c|c|c|c|c|}
\hline \multirow[t]{2}{*}{ Treatments } & \multicolumn{3}{|c|}{ Number of cloves per bulb } & \multicolumn{3}{|c|}{ Bulb yield kg/plot } & \multicolumn{3}{|c|}{ Bulb yield $q / h a$} \\
\hline & 2016-17 & 2017-18 & Pooled & 2016-17 & 2017-18 & Pooled & 2016-17 & 2017-18 & Pooled \\
\hline \multicolumn{10}{|l|}{ Bio-fertilizers } \\
\hline$B_{0}$ (Control No inoculation) & 15.23 & 16.32 & 15.78 & 2.95 & 3.14 & 3.04 & 164.00 & 174.18 & 169.09 \\
\hline $\mathbf{B}_{1}$ (Azotobacter) & 16.98 & 17.58 & 17.28 & 3.37 & 3.42 & 3.40 & 187.20 & 190.17 & 188.68 \\
\hline $\mathbf{B}_{2}$ (PGPR) & 17.48 & 17.98 & 17.73 & 3.47 & 3.55 & 3.51 & 193.03 & 197.15 & 195.09 \\
\hline B $_{3}($ Azotobacter + PGPR $)$ & 18.65 & 19.12 & 18.89 & 3.69 & 3.77 & 3.73 & 205.19 & 209.54 & 207.37 \\
\hline SEm \pm & 0.36 & 0.39 & 0.28 & 0.07 & 0.06 & 0.06 & 2.96 & 3.60 & 2.28 \\
\hline $\mathrm{CD}(\mathrm{P}=\mathbf{0 . 0 5})$ & 1.14 & 1.12 & 0.85 & 0.22 & 0.18 & 0.18 & 9.31 & 10.34 & 7.03 \\
\hline \multicolumn{10}{|l|}{ Bio-regulators } \\
\hline $\mathbf{P}_{0}$ (Control water spray) & 15.44 & 16.54 & 15.99 & 2.88 & 2.98 & 2.93 & 159.82 & 165.60 & 162.71 \\
\hline$P_{1}$ (Thiourea@500 ppm) & 17.91 & 18.47 & 18.19 & 3.57 & 3.64 & 3.61 & 198.29 & 202.48 & 200.39 \\
\hline$P_{2}$ (Thiourea @ 1000 ppm) & 18.11 & 18.88 & 18.49 & 3.67 & 3.76 & 3.71 & 203.76 & 208.97 & 206.36 \\
\hline$P_{3}$ (Salicylic acid @ 100 ppm) & 17.64 & 18.17 & 17.90 & 3.51 & 3.64 & 3.58 & 195.25 & 202.49 & 198.87 \\
\hline $\begin{array}{l}\mathbf{P}_{4} \text { (Mepiquat chloride @ } 100 \\
\text { ppm) }\end{array}$ & 16.34 & 16.69 & 16.52 & 3.23 & 3.32 & 3.28 & 179.65 & 184.25 & 181.95 \\
\hline SEm \pm & 0.36 & 0.42 & 0.30 & 0.05 & 0.10 & 0.05 & 2.98 & 3.47 & 2.58 \\
\hline $\mathrm{CD}(\mathrm{P}=\mathbf{0 . 0 5})$ & 1.03 & 1.32 & 0.84 & 0.14 & 0.30 & 0.14 & 8.56 & 10.95 & 7.30 \\
\hline
\end{tabular}


Table.4 Interactive effect of bio-fertilizers and bio-regulators on bulb yield kg/plot

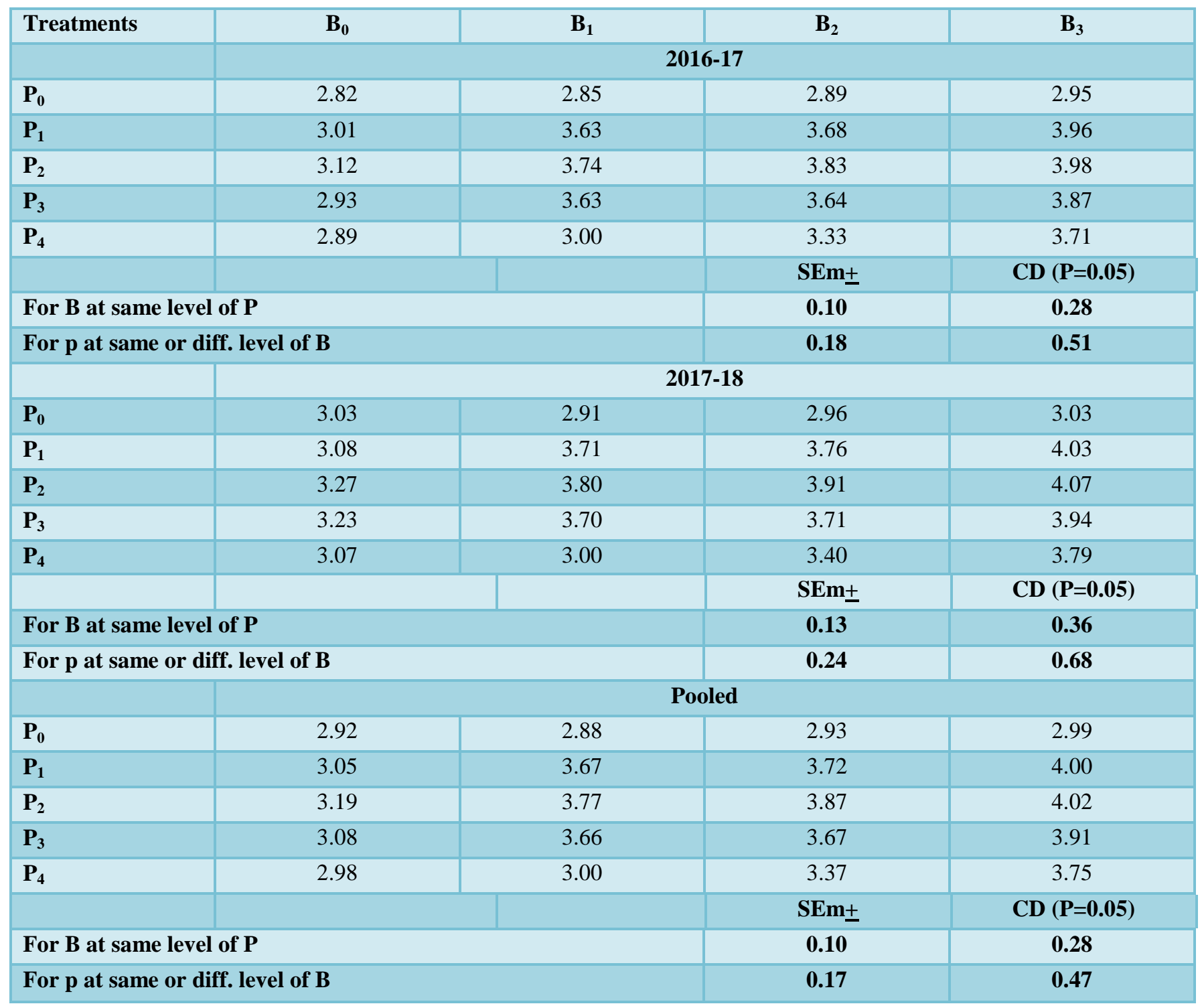


Table.5 Interactive effect of bio-fertilizers and bio-regulators on bulb yield (q/ha)

\begin{tabular}{|c|c|c|c|c|}
\hline Treatments & $\mathbf{B}_{0}$ & $\mathbf{B}_{1}$ & $\mathbf{B}_{2}$ & $\mathbf{B}_{3}$ \\
\hline \multicolumn{5}{|c|}{ 2016-17 } \\
\hline $\mathbf{P}_{0}$ & 156.46 & 158.33 & 160.63 & 163.88 \\
\hline $\mathbf{P}_{1}$ & 167.08 & 201.92 & 204.38 & 219.79 \\
\hline $\mathbf{P}_{2}$ & 173.13 & 207.63 & 213.04 & 221.25 \\
\hline $\mathbf{P}_{3}$ & 162.71 & 201.46 & 202.04 & 214.79 \\
\hline \multirow{2}{*}{$\mathbf{P}_{4}$} & 160.63 & 166.67 & 185.04 & 206.25 \\
\hline & & & $\mathrm{SEm} \pm$ & $\mathrm{CD}(\mathrm{P}=\mathbf{0 . 0 5})$ \\
\hline \multicolumn{3}{|c|}{ For $B$ at same level of $P$} & 5.96 & 17.16 \\
\hline \multicolumn{3}{|c|}{ For $p$ at same or diff. level of $B$} & 9.49 & 27.34 \\
\hline & \multicolumn{4}{|c|}{ 2017-18 } \\
\hline $\mathbf{P}_{0}$ & 168.13 & 161.46 & 164.67 & 168.17 \\
\hline $\mathbf{P}_{1}$ & 171.25 & 205.92 & 208.63 & 224.13 \\
\hline $\mathbf{P}_{2}$ & 181.46 & 211.17 & 217.33 & 225.92 \\
\hline $\mathbf{P}_{3}$ & 179.25 & 205.54 & 206.04 & 219.13 \\
\hline \multirow[t]{2}{*}{$\mathbf{P}_{4}$} & 170.79 & 166.75 & 189.08 & 210.38 \\
\hline & & & $\mathbf{S E m} \pm$ & $\mathrm{CD}(\mathrm{P}=\mathbf{0 . 0 5})$ \\
\hline \multicolumn{3}{|c|}{ For $B$ at same level of $P$} & 7.20 & 20.74 \\
\hline \multicolumn{3}{|c|}{ For $p$ at same or diff. level of B } & 11.38 & 32.78 \\
\hline & \multicolumn{4}{|c|}{ Pooled } \\
\hline $\mathbf{P}_{\mathbf{0}}$ & 162.29 & 159.90 & 162.65 & 166.02 \\
\hline $\mathbf{P}_{1}$ & 169.17 & 203.92 & 206.50 & 221.96 \\
\hline $\mathbf{P}_{2}$ & 177.29 & 209.40 & 215.19 & 223.58 \\
\hline $\mathbf{P}_{3}$ & 170.98 & 203.50 & 204.04 & 216.96 \\
\hline \multirow[t]{2}{*}{$\mathbf{P}_{4}$} & 165.71 & 166.71 & 187.06 & 208.31 \\
\hline & & & $\mathbf{S E m} \pm$ & $\mathrm{CD}(\mathrm{P}=\mathbf{0 . 0 5})$ \\
\hline \multicolumn{3}{|c|}{ For $B$ at same level of $P$} & 5.17 & 14.60 \\
\hline \multicolumn{3}{|c|}{ For $p$ at same or diff. level of $B$} & 7.98 & 22.54 \\
\hline
\end{tabular}


Interaction effect of bio-fertilizers and bioregulators on bulb yield (kg/plot)

Application of Azotobacter + PGPR and thiourea@1000 ppm/ha recorded significantly higher bulb yield $(4.02 \mathrm{~kg} / \mathrm{plot})$ over rest of the treatment combinations (Table 4). Similar results were reported by Singh and Pandey, (2006), Chattoo et al., (2007) Bhandari et al., (2012) and Sharma (2014).

The increase in bulb yield owing to this treatment may be due to the fact that $\mathrm{N}$ and $\mathrm{P}$ play an important role in synthesis of chlorophyll and amino acid (Black, 1967) and Azotobacter and PGPR ensured the continuous supply of these nutrients, very limited work has been earned out on the use of bio-fertilizers in garlic. However, Yadav et al., (2004), Senapati et al., (2005), Velmurugan and Chezhiyan (2005), Singh and Pandey (2006), Anonymous (2007), Balemi et al., (2007), Bhandari et al., (2012), Choudhary et al., (2014), Banjare et al., (2015) and Sachin at al. (2017) in garlic (Table 5). Maximum bulb yield of garlic was registered with treatment Azotobacter + PGPR both were found significantly inferior to rest of the treatments. Insufficient supply of nutrients along with reduced growth parameters and poor yield attributes might be the reason for lower bulb yield in these treatments.

Application of Azotobacter+PGPR along with thiourea @ 1000 ppm/ha. recorded maximum bulb yield of garlic $(223.58 \mathrm{q} / \mathrm{ha})$. The combined application of Azotobacter + PGPR with thiourea@1000 ppm /ha. showed significantly higher bulb yield over rest of treatment combinations.

It may be concluded on the basis of results of two-year experiments that the combined application of Azotobacter + PGPR (Pseudomonas) along with thiourea@1000 was found significantly better in terms of yield, net returns and $\mathrm{B}$ : $\mathrm{C}$ ratio $\left(223.58 \mathrm{q}^{-} \mathrm{ha}^{-}\right.$ , $₹ 189332$ and 2.40), respectively. Although, application of (Azotobacter + PGPR (Pseudomonas) + thiourea @ 500 ppm) and (Azotobacter + PGPR (Pseudomonas) + salicylic acid @ 100 ppm were found statistically at par to it.

\section{References}

Anonymous, 1999. Influence of drought ameliorative measures on leaf metabolism of cluster bean. Annual Progress Report. All India co- ordinated Research Project on Arid Legumes. Central Arid zone Research Institute, Jodhpur, Raj. pp. 133.

Anonymous, 2007. Effect of integrated nutrient management in garlic in garlic variety Yamuna Safed-4 (G-323). National Horticultural Research and Development Foundation, Nashik, pp.13.

Balai, L.R. and Keshwa, G.L. 2011. Effect of thiourea on yield and nutrient uptake of coriander (Coriandrum sativum L.) varieties under normal and late sown conditions. Journal of Spice and Aromatic Crops, 20 (1): 34-37.

Balemi, T., N. Pal, N. and Saxena, A.K. 2007. Response of onion (Allium cepa L.) to combined application of biological and chemical nitrogenous fertilizers. Acta Agricultural Slovenica, 89 (1): 1 07114.

Banjare, Chetna, Shukla, Neeraj, Sharma, P.K., Patanwar, Mridubhashini and Chandravanshi, Deepika 2015. Effect of organic substances on yield and quality of onion (Allium cepa L.). International Journal of Farm Sciences, 5 (1): 30-35.

Bhandari, S.A., Patel, K.S. and Nehete, D.S. 2012. Effect of integrated nutrient management on growth, yield and quality of garlic (Allium sativum L.) $\mathrm{cv}$. 
Gujarat Garlic-3. The Asian Journal of Horticulture, 7 (1): 48-51.

Bochalia, G.C., Tiwari, R.C., Ram, B., Kantwa, S.R. and Choudhary, A.C. 2011. Response of fenugreek (Trigonella foenum-graecum L.) genotypes to planting geometry, agrochemicals and Sulphur levels. Indian Journal of Agronomy, 56 (3): 273-279.

Chattoo, M.A., Ahmed, N., Faheema, S., Narayan, S., Khan, S.H. and Hussain, K. 2007. Response of garlic (Allium sativum L.) to bio-fertilizer. The Asian Journal of Horticulture, 2 (2): 249-252.

Choudhary, K.M.; Kavita, A.; Maurya, I.B.; Singh. B.; Sharma, M.K. and Hatwal, P.K. 2014. Effect of biofertilizers and micronutrients on growth and yield of garlic (Allium sativum L.) var. G-282. Progressive Horticulture, 46 (2): 367371.

Fisher, R.A. and Yates, F. 1963. Statistical Tables. Oliver and Boyd, Edinburgh, London.

Gupta, D.K. and Yadav, S.S. 2009. Response of fenugreek to varying levels of Sulphur and bio-regulators. Published by S.K.N. College of Agriculture in National seminar on Spices and Aromatic plants in $21^{\text {st }}$ century India, pp. 67.

Hayat, Q., Hayat, S., Irfan, M. and Ahmad, A. 2010. Effect of exogenous salicylic acid under changing environment. Environmental and Experimental Botany, 68: 14-25.

Jaafari, N. and Hadavi, E. 2012a. Growth and essential oil yield of Basil (Ocimum basilicum L.) as affected by foliar spray of citric acid and salicylic acid. Journal of Medicinal and Spices Plants, 17 (2): 80-83.

Jaafari, N. and Hadavi, E. 2012b. Growth and essential oil yield of Dill (Anethum graveolens) as affected by foliar sprays of citric acid and malic acid. Acta
Horticulture, 9 (55): 287-290.

Kore, M.S., Shembekar, R.Z., Chopde, N.K., Kuchanwar, O.D., Pillewan, S.S. and Godse, S.B. 2006. Nutrient management in garlic (Allium sativum L.). Journal of Soils and Crops, 16 (2): 465-468.

Mayer, A.M. 1956. The action of thiourea as a germination stimulator. Journals of Experimental Botany, 7: 93-96.

Mayer, A.M. and Poljakoff-Mayber, A. 1958. The interaction of thiourea and ascorbic acid in their effect on germination and growth. Bulletin of the Research Council of Israel, 6D: 103-107.

Nehra, K.C., Kumawat, P.D. and Singh, B.P. 2006. Response of fenugreek (Trigonella foenum-graecum) to phosphorus, Sulphur and plant growth regulators under semi-arid plains zone of Rajasthan. Indian Journal of Agronomy, 51 (1): 73-76.

Pachouri, C.P., Pachouri, S.P., Saraf, R.K. and Kushwaha, S.S. 2005. Influence of NPK fertilizers on yield and yield contributing parameters of garlic cultivars G 282. National Seminar on Agrotechnology, Quality Processing and Export of Species. pp. 85.

Sachin, A.J., Bhalerao, P.P. and Patil, S.J. 2017. Effect of organic and inorganic sources of nitrogen on growth and yield of garlic (Allium sativum L.) var. GG-4. International Journal of Chemical Studies, 5 (4): 559562.

Senapati, H.K., Pal, A.K. and Samant, P.K. 2005. Effect of chemical fertilizer, organic manure, lime and bio-fertilizer on yield of turmeric (Curcuma longa L.). Indian Journal Agriculture Science, 75 (9): 593-595.

Shanu, I.S., Naruka, P.P., Singh, R.P.S., Shekhawat and Verma, K.S. 2013. Effect of seed treatment and foliar spray of thiourea on growth, yield and quality of coriander (Coriandrum sativum L.) 
under different irrigation levels. International Journal of Seed Spices, 3 (1): 20-25.

Sharma, S. 2014. Effect of Integrated Nutrient Management on growth, yield and quality of kharif onion (Allium cepa L.). M.Sc. (Ag.) Thesis submitted to SKRAU, Bikaner.

Simaei, M., Khavari-Nejad, R.A. and Bernard, F. 2012. Exogenous application of salicylic acid and nitric oxide on the ionic contents and enzymatic activities in $\mathrm{NaCl}$-stressed soybean plants. American Journal of Plant Sciences, 3: 1495-1503.

Singh, V. and Pandey, M. 2006. Effect of integrated nutrient management on yield of nutrient uptake by onion and on soil fertility. Indian Journal of Society Soil Science, 54 (3): 365-367.
Somani, L.L., Bhandari, S.C., Sexena, S.N. and Gulati, I.J. 1990. Phosphors microorganism. Scientific Publishers, Jodhpur, pp. 271-290.

Velmurugan, M. and Chezhiyan, N. 2005. Effect of organic manures and biofertilizer on growth, yield and quality of turmeric (Curcuma longa L.) cv. BSR 2. South Indian Horticulture, 53 (1-6): 392-396.

Yadav, B.D., Khandelwal, R.B. and Sharma, Y.K. 2004. Use of bio-fertilizer (Azospirillum) in onion. Haryana Journal of Horticultural Sciences, 33 (3/4): 281-283.

Yawalkar, K.S., Agarwal, j.P. and Bokde, S. 1996. Manures and fertilizers. Edi. VIII, Agriculture-Horticultural Publishing House 52, Nagpur, pp. 297-299.

\section{How to cite this article:}

Ganpat Lal Yadav, S. P. Singh, R. K. Yadav and Bhagchand Yadav. 2020. Effect of Azotobacter, Pseudomonas and Bio-Regulators on Yield Attributes and Yield of Garlic (Allium sativum L.). Int.J.Curr.Microbiol.App.Sci. 9(05): 131-142.

doi: https://doi.org/10.20546/ijcmas.2020.905.014 